\title{
KEANEKARAGAMAN JENIS JAMUR MAKROSKOPIS di HUTAN HALAWILA DESA KAKAHA KABUPATEN SUMBA TIMUR
}

\section{(Diversity Of Macroscopic Mushrooms in Halawila Forest, Kakaha Village, East Sumba Regency)}

\author{
Simon Umbu Djuku ${ }^{1}$, Yohana Makaborang ${ }^{1}$, Ospensius Kawawu Taranau ${ }^{1}$ \\ Program Studi Pendidikan Biologi, Fakultas Keguruan dan Ilmu Pendidikan \\ Universitas Kristen Wira Wacana Sumba \\ E-mail: umbusimon02@gmail.com
}

\begin{abstract}
This study aims to determine the types of macroscopic fungi found in the Halawila forest, Kakaha Village, East Sumba District, which are utilized from the results of the study as a learning resource in the form of a pocket book used by students in the learning process in the classroom. The method used in this research is transect quadratic and the sampling technique in this study is purposive sampling and analyzed using a quantitative approach. The macroscopic mushroom samples found were counted using a quadratic transect technique with a plot size of $20 \times 20$ meters, with a line transect stretched as far as 200 meters at each sampling station. The study was divided into three stations, each station was divided into 5 plots. The distance between each plot is 25 meters. The results obtained were 10 types of macroscopic fungi consisting of 3 orders and 3 families. The types of mushrooms are Daedaleopsis confragosa, Hexagonia tenius, Microporus affinis, Pycnoporus cinnabarius, Lentinus tigrinus, Genoderma appalatum, Picipes badius, Fomes fomentarius, Herecium erinaceus Auricularia auricula-judae. Theindex diversity macroscopic mushroomin the Halawila forest, Kakaha village,district is Sumba Eastclassified as moderate with an index value of $H^{\prime}=1.633$.
\end{abstract}

Keywords: Diversity, Macroscopic Fungus.

\begin{abstract}
ABSTRAK
Penelitian ini bertujuan untuk mengetahui jenis-jenis jamur makroskopis yang terdapat di hutan Halawila Desa Kakaha Kabupaten Sumba Timur yang dimanfaatkan dari hasil penelitian sebagai sumber belajar dalam bentuk buku saku yang di gunakan oleh siswa dalam proses pembelajaran di dalam kelas. Metode yang digunakan dalam penelitian ini adalah transek kuadrat dan teknik pengambilan sampel dalam penelitian ini purposive sampling dan dianalisis menggunakan pendekatan kuantitatif. Sampel jamur makroskopis yang ditemukan di hitung menggunakan teknik transek kuadrat dengan ukuran setiap plot 20x20 meter, dengan garis transek yang dibentangkan sejauh 200 meter pada setiap stasiun pengambilan sampel. Penelitian terbagi atas tiga stasiun, setiap stasiun dibagi menjadi 5 plot. Jarak antara setiap plot adalah 25 meter. Hasil penelitian yang diperoleh adalah 10 jenis jamur makroskopis yang terdiri dari 3 ordo dan 3 family. Jenis-jenis jamur tersebut yaitu, Daedaleopsis confragosa, Hexagonia tenius, Microporus affinis, Pycnoporus cinnabarius, Lentinus tigrinus, Genoderma appalatum, Picipes badius, Fomes fomentarius, Herecium erinaceus Auricularia auricula-judae. Indeks keenekaragaman jamur makroskopis di hutan Halawila desa Kakaha kabupaten Summba Timur tergolong sedang dengan nilai indeks $H^{\prime}=1,633$.
\end{abstract}

Kata kunci: Keanekaragaman, Jamur Makroskopis. 


\section{PENDAHULUAN}

Indonesia memiliki keanekaragaman flora terlihat pada kelimpahan hutan tropiknya, hutan tropik yang terdapat di dataran rendah maupun hutan tropik terdapat di dataran tinggi yang menutupi $63 \%$ luas daratan Indonesia. Keanekaragaman hayati yang terdapat di hutan tropik adalah salah satunya jamur. Di hutan-hutan inilah sebagian besar dijumpai tumbuhan yang merambat, berbentuk perdu, dan pohon dengan bermacam - macam ukuran, selain itu juga terdapat organisme lain seperti jamur, lumut dan ganggang (Iswanto, 2009). Salah satu organisme yang memegang peranan penting dalam daur kehidupan adalah jamur. Peranan penting dari jamur adalah menguraikan bahan organik kompleks yang ada di dalam dan menjadi suatu unsur yang sangat sederhana sehingga mudah diserap dan dimanfaatkan oleh organisme lainnya, (Nuhamara et al., 2017). Dalam ekosistem, jamur mempunyai peranan yang sangat penting sebagai pengurai dan menjadi penyeimbang keanekaragaman jenis hutan. Jamur mampu menguraikan bahan organik menjadi senyawa yang diserap dan digunakan untuk pertumbuhan dan perkembangan (Hasanuddin, 2014:).

Jamur merupakan organisme yang tidak berklorofil, spesies ini memiliki ukuran dan bentuk yang berbeda-beda dan memiliki peran penting bagi kehidupan makhluk hidup lain (Waretno, 2017). Jamur makroskopis adalah jamur yang dapat dilihat dengan kasat mata. Karakteristiknya dapat dilihat berdasarkan struktur dan bentuk tubuhnya. Morfologi jamur makroskopis mempunyai warna tubuh bervariasi yaitu warna coklat, merah, orange muda, kuning langsat, putih, putih kekuningan, hijau, kelabu dan hitam. Jamur makroskopis memiliki bentuk tubuh buah seperti kipas, ginjal, setengah lingkaran, terompet dan payung (Rahma, et al., 2018). Jamur tidak termasuk ke dalam kelompok organisme yang mampu membuat makanan sendiri karena tidak mampu untuk berfotosintesis (Waretno 2017). Menurut Munir (2006), Jamur, khususnya kelompok jamur makroskopis atau makrofungi (Basidiomycota), merupakan kelompok utama organisme pendegradasi lignoselulosa karena mampu menghasilkan enzim-enzim pendegradasi lignoselulosa seperti selulase, ligninase, dan hemiselulase sehingga siklus materi di alam dapat terus berlangsung. Jamur mendapatkan nutrisi dengan cara menyerap zat-zat makanan dari bahan organik disekitar tempat tumbuhnya yang diubah menjadi molekul-molekul sederhana sehingga jamur dapat bertahan hidup dengan memanfaatkan inangnya (Iswanto, 2009).

Umumnya jamur hidup di berbagai tipe habitat yaitu kayu, tanah, serasah, kotoran hewan dan sebagainya. Hutan adalah tipe ekosistem yang dapat ditumbuhi jamur, karena hutan memiliki tingkat kelembapan yang tinggi sehingga jamur mudah beradaptasi (Annissa et al., 2017). Selain itu, kelompok jamur makroskopis secara nyata mempengaruhi jaring-jaring makanan di hutan, kelangsungan hidup atau perkecambahan anakan-anakan pohon, pertumbuhan pohon, dan keseluruhan kesehatan hutan (Molina et al., 2001). Jadi, keberadaan jamur makroskopis adalah komponen penting dalam komunitas hutan yang berubah - ubah.

\section{METODE PENELITIAN}

Penelitian ini merupakan jenis penelitian deskriptif ekologis yang berdasarkan pada pendekatan kuantitatif. Penelitian ini dilakukan di hutan Halawila Desa Kakaha, Kecamatan Ngadu ngala, Kabupaten Sumba Timur. penelitian ini dilaksanakan pada bulan Mei - Juli 2021 di kawasan hutan Halawila. Populasi pada penelitian ini adalah seluruh jamur makroskopis yang terdapat atau ditemukan di lokasi penelitian. Teknik pengambilan sampel dilakukan dengan metode purposive sampling, 
yaitu dengan membuat jalur garis transek di beberapa lokasi yang mewakili jamur makroskopis.

Alat yang diperlukan dalam penelitian ini adalah tali plastik, meter roll, penggaris, kamera, alat tulis menulis, thermometer, $\mathrm{pH}$ meter, kaos tangan, box sampel, gunting, papan data, kantong, penjepit. Bahan yang diperlukan dalam penelitian ini adalah alkohol
$70 \%$ dan kertas label. Penelitian ini menggunakan metode transek kuadrat dengan cara membuat 3 stasiun yaitu yang di bentangkan sejauh 200 meter pada setiap stasiun pengambilan sampel. Setiap stasiun dibagi menjadi 5 plot. Ukuran setiap plot yaitu $20 \times 20$ meter. Jarak antara tiap plot yaitu 25 meter

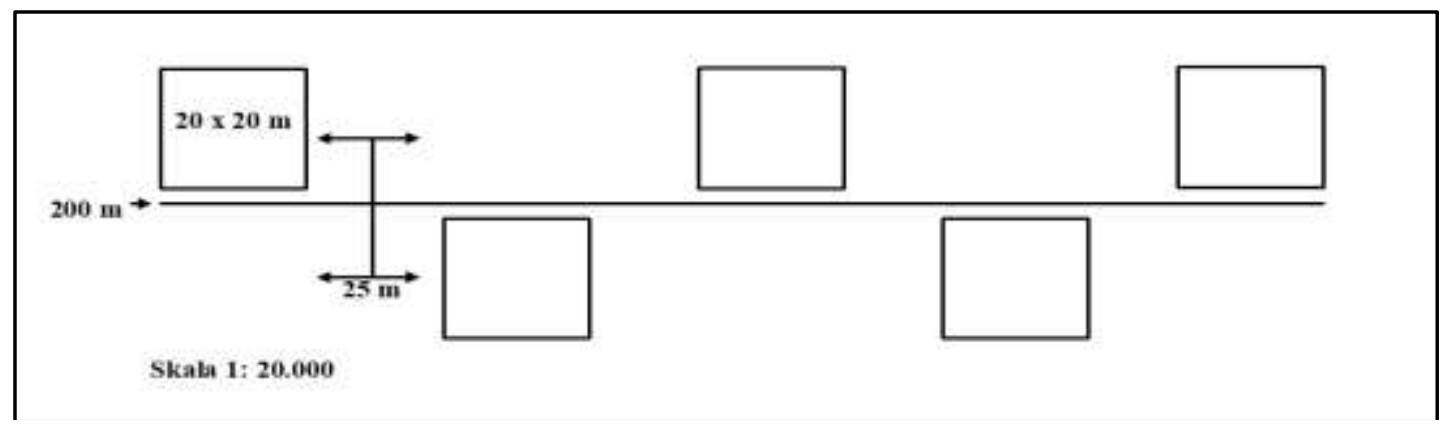

Gambar 1. Desain Transek Kuadrat

Identifikasi jamur makroskopis di hutan Halawila desa Kakaha kabupaten Sumba Timur menggunakan buku acuan Suhardiman, (1995), dilakukan Di Laboratorium Terpadu Universitas Kristen Wira Wacana Sumba. Penlitian ini akan dianalisis secara deskriptif. Kemudian sampel yang diperoleh dari lokasi penelitian dilakukan identifikasi berdasarkan karakter morfologi untuk menentukan jenisjenisnya beserta indeks keanekaragamannya.

\section{Indikator Ekologi Kerapatan}

Kerapatan adalah jumlah individu per unit luas atau per unit volume. kerapatan juga merupakan jumlah individu persatuan ruang. kerapatan spesies, kerapatan spesies ke-I dapat dihitung sebagai $\mathrm{K}-\mathrm{i}$, dan kerapatan relatif setiap spesies ke-i terhadap kerapatan total dapat dihitung sebagai KR-i.
Menurut Indriyanto (2006) rumus kerapatan dan kerapatan relatif dapat dihitung sebagai berikut: $\quad \mathrm{Di}=\frac{\mathrm{ni}}{\mathrm{A}}$

Keterangan :

Di : kerapatan jenis

ni : jumlah total individu jenis

A : luas daerah yang disampling

\section{Kerapatan relatif}

Kerapatan Relatif adalah perbandingan kerapatan suatu jenis vegetasi dengan kerapatan seluruh jenis vegetasi dalam suatu area (Indriyanto,2006).

$$
K R=\frac{n i}{N} \times 100 \%
$$

$\mathrm{KR}$ : kerapatan relatif

ni : kerapatan spesies ke $-\mathrm{i}$

$\mathrm{N}$ : kerapatan seluruh spesies

\section{Frekuensi}

Frekuensi merupakan parameter yang digunakan untuk menyatakan proporsi antara jumlah sampel yang terdapat suatu spesies tertentu terhadap jumlah total sampel. 
Frekuensi juga merupakan besarnya intensitas ditemukannya suatu spesies organisme pada pengamatan keberadaan organisme pada komunitas atau ekosistem (Indriyanto,2006).

$$
\text { F } \frac{\text { jumlah plot ditemukannya suatu spesies }}{\text { jumlah seluruh plot }}
$$

\section{Frekuensi relatif}

Menurut (Indriyanto 2006) Frekuensi Relatif adalah persentase perbandingan antara frekuensi suatu jenis vegetasi dengan frekuensi seluruh jenis vegetasi dalam area.

$$
\mathrm{FR}-\mathrm{i}=\frac{\text { frekuensi suatu spesies } \mathrm{ke}-\mathrm{i}}{\text { frekuensi seluruh spesies }} \times 100 \%
$$

\section{Indeks Ekologi \\ Indeks keanekaragaman}

Menurut (Indriyanto, 2006) sampel yang diperoleh di dalam setiap petak pengamatan dianalisis secara kuantitatif dengan rumus Shannon Wiener sebagai berikut:

$\mathrm{H}^{\prime}=-\sum$ pi In pi dimana $: \mathrm{pi}=\mathrm{ni} / \mathrm{N}$

Keterangan:

$\mathrm{H}^{\prime}=$ indeks keanekaragaman shannomwiener .

$\mathrm{Pi}=$ kelimpahan relatif spesies ke-i

ni = jumlah individu dari suatu jenis.

$\mathrm{N}=$ jumlah total individu seluruh jenis.

Berdasarkan indeks keanekaragaman jenis menurut shannon- wienner diidentifikasi sebagai berikut:

Nilai $H^{\prime} \geq 3$ menunjukkan bahwa keanekaragaman pada suatu transek melimpah tinggi. Nilai $1 \leq \mathrm{H} \leq 3$ menunjukkan bahwa keanekaragaman spesies pada suatu transek memiliki kelimpahan sedang. Nilai $\mathrm{H} \leq 1$ menunjukkan bahwa keanekaragaman spesies pada suatu transek adalah rendah.

\section{Indeks kemerataan}

Untuk mengetahui keseimbangan komunitas digunakan indeks kemerataan, yaitu ukuran kesamaan jumlah individu antar spesies dalam suatu komunitas (Indriyanto,2006). Semakin mirip jumlah individu antar spesies (semakin merata penyebarannya) maka semakin besar derajat keseimbangan. Rumus indeks kemerataan (e) diperoleh dari :

$\mathrm{E}=\mathrm{H}^{\prime} / \mathrm{Lns}$
keterangan:

$\mathrm{E}=$ indeks kemerataan

$\mathrm{H}^{\prime}=$ indeks keanekaragaman

$\mathrm{S}=$ banyaknya spesies dengan nilai e berkisar pada 0-1

Adapun kategori indeks kemerataan sebagai berikut: Nilai $0,0<\mathrm{E} \leq 0,50$ menunjukkan bahwa kemerataan komunitas tertekan. Nilai $0,50<\mathrm{E} \leq 0,75$ menunjukkan bahwa kemerataan komunitas tidak stabil. Nilai 0,75 $<\mathrm{E} \leq 1,00$ menunjukkan bahwa kemerataan komunitas stabil.

\section{Indeks dominansi}

Indeks Dominansi dihitung dengan menggunakan rumus indeks dominansi dari Simpson (Indriyanto, 2006).

Keterangan:

$$
D=\sum(n i / N)^{2}
$$

$\mathrm{D}=$ Indeks Dominansi Simpson

$\mathrm{Ni}=$ Jumlah Individu tiap spesies

$\mathrm{N}=$ Jumlah Individu seluruh spesies

Indeks dominansi berkisar antara 0 sampai 1, dimana semakin kecil nilai indeks dominansi maka menunjukan bahwa tidak ada spesies yang mendominasi sebaliknya semakin besar dominansi maka menunjukkan ada spesies tertentu.

Adapun kategori indeks dominansi sebagai berikut:

Nilai $0,0<\mathrm{D} \leq 0,50$ menunjukkan bahwa dominansi rendah.

Nilai $0,50<\mathrm{D} \leq 0,75$ menunjukkan bahwa dominansi sedang.

Nilai $0,75<\mathrm{D} \leq 1,00$ menunjukkan bahwa dominansi tinggi.

HASIL DAN PEMBAHASAN 
Volume 3 Nomor 2 Desember 2021:32-40

Jenis-jenis jamur makroskopis yang ditemukan di hutan Halawila

Berdasarkan hasil penelitian jamur makroskopis yang telah dilakukan di hutan Halawila Desa Kakaha Kabupaten Sumba Timur maka diketahui bahwa jumlah jamur makroskopis yang ditemukan sebanyak 10 jenis. Jumlah individu yang ditemukan dikawasan hutan Halawila sebanyak 496 individu yang terdiri 3 stasiun. Stasiun 1 sebanyak 166 individu, stasiun 2 sebanyak 159 individu dan stasiun 3 sebanyak 171 individu. Adapun tabel hasil identifikasi jamur makroskpis di hutan Halawila.

Tabel 1. Hasil identifikasi jamur makroskopis di setiap stasiun

\begin{tabular}{clcccc}
\hline \multirow{2}{*}{ No. } & \multicolumn{1}{c}{ Nama Spesies } & I & II & III & Total \\
\cline { 3 - 5 } Individu \\
\hline 1 & Daedaleopsis confragosa & 46 & 68 & 57 & 171 \\
2 & Hexagonia tenius & 64 & 48 & 68 & 180 \\
3 & Microporus affinis & 9 & 6 & 11 & 26 \\
4 & Pycnoporus cinnabarinus & 10 & 12 & 5 & 27 \\
5 & Auricularia auricula-judae & 6 & 9 & 11 & 26 \\
6 & Lentinus tigrinus & 8 & 7 & 6 & 21 \\
\hline 7 & Genoderma applanatum & 10 & 7 & 5 & 22 \\
8 & Picipes badius & 10 & 2 & 7 & 19 \\
9 & Fomes fomentarius & 2 & 0 & 1 & 3 \\
10 & Herecium erinaceus & 1 & 0 & 0 & 1 \\
& Jumlah total individu & 166 & 159 & 171 & 496 \\
\hline
\end{tabular}

Tabel 1 diatas menunjukkan hasil identifikasi jamur Makroskopis di hutan Halawila Desa Kakaha sebanyak 10 spesies yang ditemukan yaitu Daedaleopsis confragosa sebanyak 171 individu, Hexagonia tenius sebanyak 180 individu, Microporus affinis sebanyak 26 individu, Pycnoporus cinnabarius sebanyak 27 individu, Aurucularia auricula-judae sebanyak 26

\section{Hasil pengamatan indikator ekologi}

Hasil penelitian yang sudah dilakukan dengan indikator ekologi meliputi indikator kerapatan, kerapatan relatif, frekuensi, individu, Lentinus tigrinus sebanyak 21 individu, Genoderma appalanatum sebanyak 22 individu, Picipes badius sebanyak 19 individu, Fomes fomentarius sebanyak 3 individu, Herecium erinaceus sebanyak 1 spesies, jadi total keseluruhan individu yang ditemukan di Hutan Halawila adalah 496 individu.

frekuensi relatif. Berikut jamur makroskopis yang terdapat pada beberapa stasiun berdasarkan indikator ekologi disajikan pada Tabel 2.

Tabel 2. Indikator ekologi

\begin{tabular}{rlcccc}
\hline No & Nama Spesies & Di & KR & Fi & FR \\
\hline 1 & Daedaleopsis confragosa & 0,0285 & $34 \%$ & 0,344 & $35 \%$ \\
2 & Hexagonia tenius & 0,0300 & $36 \%$ & 0,362 & $36 \%$ \\
3 & Microporus affinis & 0.0043 & $5 \%$ & 0,052 & $5 \%$ \\
\hline 4 & Pycnoporus cinnabarinus & 0,0045 & $5 \%$ & 0,054 & $5 \%$ \\
5 & Auricularia auricula-judae & 0,0043 & $5 \%$ & 0,052 & $5 \%$
\end{tabular}


Volume 3 Nomor 2 Desember 2021:32-40

\begin{tabular}{clcccc}
6 & Lentinus tigrinus & 0,0035 & $4 \%$ & 0,042 & $4 \%$ \\
7 & Genoderma applanatum & 0,0036 & $4 \%$ & 0,044 & $4 \%$ \\
8 & Picipes badius & 0,0031 & $4 \%$ & 0,038 & $4 \%$ \\
9 & Fomes fomentarius & 0,0005 & $0 \%$ & 0,006 & $1 \%$ \\
10 & Herecium erinaceus & 0,0001 & $0 \%$ & 0,002 & $0 \%$ \\
\hline & & 0,0824 & $100 \%$ & 0,996 & $100 \%$ \\
\hline
\end{tabular}

Berdasarkan tabel 2. menunjukkan indikator ekologi kerapatan jenis jamur makroskopis dapat dilihat pada spesies Hexagonia tenius $\mathrm{Di}=0,0300$, sedangkan spesies yang tingkat kerapatan rendah adalah Herecium erinaceus dengan kerapatan 0,0001. Spesies yang menunjukkan kerapatan relatif tinggi adalah spesies Hexagonia tenius dengan kerapatan relatif

\section{Hasil pengamatan indeks ekologi.}

Indeks ekologi yang digunakan adalah indeks keanekaragaman, indeks kemerataan dan indeks dominansi. Indeks keanekaragaman jamur makroskopis di hutan Halawila desa Kakaha kabupaten Sumba Timur menunjukkan angka $\mathrm{H}^{\prime}=$ 1,633 termasuk kategori sedang. Indeks sebesar 36\%. Hasil indikator ekologi yang tinggi pada frekuensi jenis adalah spesies Hexagonia tenius dengan frekuensi 0,362, frekuensi relatif yang paling tinggi adalah spesies Hexagonia tenius dengan frekuensi relatif $36 \%$. Frekuensi relatif yang paling rendah adalah spesies Fomes fomentarius dan spesies Herecium erinaceus dengan frekuensi relatif $0 \%$.

kemerataan jamur makroskopis di hutan Halawila Desa Kakaha Kabupaten Sumba Timur menunjukkan angka $\mathrm{E}=0,263$ termasuk kategori tertekan. Indeks dominansi jamur makroskopis di hutan Halawila desa Kakaha kabupaten Sumba Timur menunjukkan angka sebesar 0,999996 termasuk kategori tinggi.

\section{Hasil Pengamatan Faktor Fisik lingkungan di hutan Halawila Desa Kakaha}

Adapun hasil pengukuran faktor abiotik pada lokasi penelitian hutan halawila Desa Kakaha. 

Volume 3 Nomor 2 Desember 2021:32-40

Tabel 3. Hasil pengukuran faktor abiotik

\begin{tabular}{|c|c|c|c|c|c|}
\hline \multirow{2}{*}{ No. } & \multirow{2}{*}{ Faktor fisik } & \multicolumn{3}{|c|}{ Stasiun } & \multirow{2}{*}{$\begin{array}{c}\text { Rata-rata } \\
\text { keseluruhan }\end{array}$} \\
\hline & & 1 & 2 & 3 & \\
\hline \multirow[t]{4}{*}{1.} & Suhu & & & & \\
\hline & Hari ke 1 & $30 \mathrm{C}^{\circ}$ & $29 C^{\circ}$ & $32 \mathrm{C}^{\circ}$ & $30 \mathrm{C}^{\circ}$ \\
\hline & Hari ke 2 & $30 \mathrm{C}^{\mathrm{o}}$ & $32 \mathrm{C}^{\mathrm{o}}$ & $33 \mathrm{C}^{\mathrm{o}}$ & $31 \mathrm{C}^{\mathrm{o}}$ \\
\hline & Hari ke 3 & $32 \mathrm{C}^{\circ}$ & $30 \mathrm{C}^{\mathrm{o}}$ & $31 \mathrm{C}^{\mathrm{o}}$ & $31 \mathrm{C}^{\mathrm{o}}$ \\
\hline \multirow[t]{4}{*}{2.} & Kelembapan & & & & \\
\hline & Hari ke 1 & $81 \%$ & $83 \%$ & $81 \%$ & $81 \mathrm{C}^{\circ}$ \\
\hline & Hari ke 2 & $82 \%$ & $85 \%$ & $86 \%$ & $84 \mathrm{C}^{\mathrm{o}}$ \\
\hline & Hari ke 3 & $86 \%$ & $87 \%$ & $88 \%$ & $87 \mathrm{C}^{\circ}$ \\
\hline \multirow[t]{4}{*}{3.} & $\mathrm{pH}$ & & & & \\
\hline & Hari ke 1 & 7,0 & 6,8 & 7,0 & 6,9 \\
\hline & Hari ke 2 & 6,5 & 6,5 & 6,0 & 6,3 \\
\hline & Hari ke 3 & 6,5 & 6,0 & 6,0 & 6,1 \\
\hline
\end{tabular}

Berdasarkan tabel diatas hasil pengukuran faktor abiotik pada lokasi penelitian menunjukan, pengukuran suhu tanah berkisar dari $29-33 \mathrm{C}^{\mathbf{o}}$ dengan melakukan pengulangan selama tiga kali. Hasil pengukuran pH tanah berkisar mulai dari 6,0 - 7,0 dengan melakukan tiga kali pengulangan setiap harinya. Hasil pengukuran kelembapan tanah pada lokasi penelitian menunjukan angka yang berkisar mulai dari $81 \%-88 \%$.

\section{Kerapatan dan kerapatan relatif}

Jamur makroskopis di hutan Halawila memiliki kerapatan tertinggi pada spesies Hexagonia tenius dengan jumlah $\mathrm{Di}=0,0300$ dan kepadatan relatif sebesar $36 \%$. Spesies banyak menempati tempat yang lembab dan basah seperti serasah kayu dan tumpukan dedaunan yang masih basah dan lembab, menurut Ulya et al, (2017) spesies dari ordo Polyporales sering ditemukan menempel di batang pohon yang sudah mati dan berada pada tumpukan kayu mati serta hidup parasit pada tumbuhan lain. Kerapatan spesies ini di pengaruhi oleh habitat tempat spesies ini hidup karena jamur ini paling mampu beradaptasi dengan lingkungan dengan kondisi yang berubah - ubah akibat iklim seperti suhu, intensitas cahaya dan kelembapan.

Spesies yang memiliki kerapatan terendah adalah Herecium erinaceus dengan jumlah $\mathrm{Di}=$ 0,0001 dan kepadatan relatif sebesar 0\%. Hal ini dikarenakan jumlah individu yang didapati hanya 1 individu saat pengambilan sampel dilapangan. Spesies ini jarang ditemukan karena berada pada habitat tertentu saja, spesies ini dapat hidup saat curah hujan tinggi dan keadaan tanah, kayu dan pepohonan yang sangat lembab, hal ini sejalan dengan pernyataan Kunca \& Ciliak (2016) yang menyatakan spesies Herecium erinaceus hidup pada pepohonan dan kayu mati serta ada juga yang menempel pada pohon yang masih hidup, adapatasi spesies ini sangat rendah dibandingkan dengan spesies lain.

\section{Frekuensi dan frekuensi relatif}

Berdasarkan hasil perhitungan jamur yang memiliki frekuensi tertinggi pada speseies Hexagonia tenius dengan nilai $\mathrm{Fi}=0,362$ dan frekuensi relatif sebesar 36\%. Spesies ini memiliki substrat pada kayu yang sudah mati, daun yang sudah lapuk dan spesies ini juga tumbuh secara bergerombol pada substratnya dan tumbuh paling dominan lokasi penelitian sehingga memiliki frekuensi tertinggi. Spesies yang memiliki frekuensi terendah pada spesies Herecium erinaceus dengan nilai $\mathrm{Fi}=0,002$ dan frekuensi relatif $0 \%$. Spesies dari ordo Russulales ini memiliki hidup yang lemah parasit, jamur yang berhabitat pada kayu mati dan kadang-kadang tumbuh pada lubang-lubang kecil atau kayu yang retak dan masih hidup, Karena spesies satu ini lemah parasitnya sehingga berada pada frekuensi terendah (Stadler et al. 2015).

\section{Indeks Dominansi}


Lokasi penelitian memiliki indeks dominansi yang termasuk kategori tinggi yaitu 0,999. Pada penelitian ini indeks dominansinya mendekati 1, berarti ada spesies yang memiliki indeks dominansi tinggi. Hexagonia tenius merupakan spesies yang mendominasi pada penelitian ini, karena spesies ini tumbuh secara berkelompok dan persebarannya sanga luas pada pohon-pohon sehingga spesies ini sangat mendominasi. Di sisi lain juga spesies Hexagonia tenius memiliki tingkat ketahahanan hidup yang tinggi pada habitatnya. Menurut pernyataan (Hasanuddin, 2014) spesies Hexagonia tenius dapat bertahan hidup pada kayu yang sudah mati bahkan kayu yang sudah mengalami pelapukan.

\section{Tingkat kemerataan}

Hutan Halawila memiliki tingkat kemerataan yang termasuk pada kategori tertekan yaitu 0,263 . Kemerataan spesies yang tertekan dipengaruhi oleh tidak meratanya penyebaran spesies pada suatu lingkungan, berarti ada salah satu spesies yang memiliki jumlah spesies paling banyak dalam suatu lingkugan sehingga ada yang namanya tingkat kemerataan tertekan. Dalam suatu lingkungan jika ada satu spesies yang mendominasi di lingkungan tersebut maka tidak ada kemerataan dalam lokasi tersebut. Jika spesies memiliki selisih penyebaran besar maka kemerataannya semakin berkurang, sebaliknya pun jika spesies memiliki selisih penyebarannya kecil maka kemerataan spesies pun besar (Nuhamara et al, 2017).

\section{Tingkat keanekaragaman}

Hasil penelitian keanekaragaman jamur makroskopis yang telah dilakukan di hutan halawila, spesies yang memiliki jumlah individu yang paling banyak di temukan adalah Hexagonia tenius sebanyak 180 individu di setiap stasiun. Spesies ini memiliki habitat pada pohon yang sudah mati dan hidup secara bergerombol sehingga speseis ini paling banyak ditemukan di lokasi penelitian. Tingkat keanekaragaman jamur makroskopis dihutan Halawila Kabupaten Sumba Timur memiliki tingkat kategori sedang yaitu $H^{\prime}=1,633$, penyebaran spesies pada hutan halawila tidak merata karena spesies Hexagonia tenius yang paling mendominasi.

Spesies jamur makroskopis yang terdapat pada beberapa stasiun memiliki jumlah yang berbeda -beda, terdapat spesies yang tertinngi jumlahnya dan ada spesies yang terendah jumalahnya. Perbedaan tersebut menunjukkan adanya spesies yang tertinggi adalah spesies Hexagonia tenius, spesies ini memiliki individu tertinggi karena mampu beradaptasi dengan lingkungan dan mampu bertahan hidup lebih lama pada habitatnya dari pada spesies lainnya.

Kehidupan jamur makroskopis di area hutan dapat di pengaruhi oleh faktor - faktor pada lingkungan dimana jamur makroskopis tersebut hidup. Faktor linhkungan tersebut seperti suhu, kelembapan, dan $\mathrm{pH}$ (Arif, dkk, . 2007). Berdasarkan hasil pengukuran suhu pada lokasi penelitian berkisar dari $29-33 \mathrm{C}^{\circ}$. angka pada suhu tersebut menunjukkan kehidupan jamur makroskopis di hutan halawila masih dalam kategori suhu yang normal sehingga jamur makroskopis dapat bertahan hidup dengan suhu tersebut. Hasil pengukuran $\mathrm{pH}$ tanah pada lokasi penelitian dari ketiga stasiun adalah berkisar mulai dari $6,0-7,0$. Pada keadaan $\mathrm{pH}$ tanah tersebut menunjukkan kehidupan jamur makroskopis di hutan Halawila berada pada $\mathrm{pH}$ yang normal. Kelembapan tanah pada lokasi penelitian berkisar mulai $81 \%$ - $88 \%$. Kelembapan tersebut berada pada lingkungan yang normal, sehingga sangat baik untuk pertumbuhan jamur makroskopis.

Kondisi pertumbuhan jamur makrokopis dapat dipengaruhi oleh faktor-faktor lingkungan. Jika suatu lingkungan mempunyai kondisi yang buruk atau lingkungan tidak normal maka akan berpengaruh pada pertumbuhan jamur pada habitat tersebut (Gandjar, dkk 2006). Oleh karena itu, faktor lingkungan pada lokasi penelitian berada pada lingkunagan yang normal bagi kehidupan jamur makroskopis. Hasil penelitian dengan tingkat keanekaragaman sedang tidak dipengaruhi oleh faktor lingkungan melainkan di pengaruhi karena adanya aktivitas manusia berupa pengambilan jamur makroskopis di hutan tersebut. 
Volume 3 Nomor 2 Desember 2021:32-40

\section{KESIMPULAN}

Jenis Jamur makroskopis yang ditemukan di lokasi penelitian sebanyak 496 individu. Tingkat keanekaragaman jamur makroskopis dihutan Halawila desa Kakaha Kabupaten Sumba Timur memiliki tingkat kategori sedang yaitu $H^{\prime}=1,633$, penyebaran spesies pada hutan halawila tidak merata karena spesies Hexagonia tenius yang paling mendominasi. Keanekaragaman dipengaruhi oleh jumlah spesies dan jumlah individu yang di temukan di setiap stasiun.

\section{DAFTAR PUSTAKA}

Annissa, I., Ekamawanti, H. A., \& Wahdina. (2017). Keanekaragaman Jenis Jamur Makroskopis di Arboretum Sylva Universitas Tanjungpura. Jurnal Hutan Lestari, 5(4), 969-977.

Arif, A., Muin, M., Kuswinanti, T., Harviani, V. (2007:50). Isolasi dan Identifikasi Jamur Kayu dari Hutan Pendidikan dan Latihan Tabo-Tabo Kecamatan Bungoru Kabupaten Pangkep, Jurnal Perenthial, 3,(2), 49-54.

Gandjar, I., Sjamsuridzal, W., Oetari, A. (2006). Mikologi Dasar dan Terapan. Jakarta: Yayasan Obor Indonesia.

Hasanuddin. (2014:39). Jenis jamur kayu makroskopis sebagai media pembelajaran. Jurnal biotik, 2(1), 38-52.

Indriyanto.(2006). Ekologi Hutan. Jakarta: PT Bumi Aksara.

Iswanto, A. H. (2009). Identifikasi Jamur Perusak Kayu.Universitas Sumatera Utara. Retrieved from http://repository.usu.ac.id/bitstream/handl e.

Kasim, Z. S,. \& Hamid, H. (2015). Analisis Vegetasi Dan Visualisasi Struktur Vegetasi Hutan Kota Baruga, Kota Kendari. Jurnal hutan tropis, 3(2), 99109.

Kunca, V., Ciliak, M. (2016: 1). Habitat preferences of Hericium erinaceus in Slovakia. Fungal Ecologi, Retrived http://dx.doi.org/10.1016/j.funeco.2016.1 2.002
Munir, E. (2006). Pemanfaatan mikroba dalam bioremediasi: suatu teknologi alternatif untuk pelestarian lingkungan. Pidato pengukuhan jabatan guru besar tetap dalam bidang mikrobiologi FMIPA Universitas Sumatera Utara, Medan.

Molina, R., Pilz, D., Smith, J., Dunham, S., Dreibach, T., O'Dell, T., Castellano, M. (2001: 45). Conservation And Management Of Forest Fungi In The Pacific Northwestern United States: An Integrated Ecosystem Approach. Jurnal Reasearch Gate, Retrieved from https://www.researchgate.net/publication/ 230788142.

Nuhamara, S.T Solle, H., \& Klau, F. (2017:105). Keanenkaragaman Jamur di Cagar Alam Gunung Mutis Kabupaten Timor Tengah Utara, Nusa Tenggara Timur. Jurnal Biota. 2(3), 105-110.

Putir, P. E., Tunduh, Y., \& Firdara, E. K. (2019). Biodiversitas dan Identifikasi Jamur Basidiomycetes di Taman Nasional Sebangau, Kabupaten Katingan Kalimantan Tengah. Jurnal jejaring Matematika dan Sains. 1 (1), 39-43.

Rahma, K., Mahdi, N., \& Hidayat, M. (2018:157). Karakteristik jamur makroskops di perkebunan kelapa sawit kecamatan Meureubo Aceh Barat. Prosiding seminar nasional biotik 2018, ISBN: 978-602-60401-9-0, 157-164.

Stadler, R., Wittstein, K., Hyde, K, D., Rapior, S., Thongbai, B. (2015:4). Hericium Erinaceus, An Amazing Medicinal Mushroom. Retrieved from https://www.researchgate.net/publication/ 281146648.

Ulya, A,N., Leksono, S, M., Khastini, R, 0. (2017: 15). Biodiversitas dan Potensi Jamur Basidomycota Di Kawasan Kasepuhan Cisungsang, Kabupaten Lebak, Banten. Juonar Of Biology. 10(1), 2017, 9-16.

Waretno, L. (2017) inventarisasi jamur makroskopis di PT perkebunan nusantara III perkebunan karet sarang giting Dolok Masihul. (Skripsi). Fakultas Biologi Universitas Medan Area, Medan. 